\title{
WOOD ANATOMY OF THE BLAKEEAE (MELASTOMATACEAE)
}

\author{
J.KOEK-NOORMAN ${ }^{1}$, P.HOGEWEG ${ }^{2}$, W. H. M.VAN MAANE ${ }^{1}$ and B.J.H.TER \\ WELLE ${ }^{1}$
}

1. Instituut voor Systematische Plantkunde, Utrecht

2. Subfakulteit Biologie; Bioinformatica, Utrecht

\section{CONTENTS}

1. Introduction

2. Material

3. Light-microscopical investigations

3.1. Methods

3.2. Descriptions of Blakea, Topobea, and Huilaea

3.3 Discussion

4. S.E.M. investigation of pit vestures

4.1. Methods

4.2. Results

4.3. Discussion

5. Numerical analysis of a data set of wood anatomical characters of Blakeeae and Miconieae.

5.1. Methods

5.2. Results

5.3. Discussion

6. Conclusions

\section{SUMMARY}

The present paper deals with the wood anatomy of the Blakeeae (Melastomataceae). Generic descriptions of the secondary xylem of Blakea, Topobea, and Huilaea are given and compared with data on 16 genera of the Miconieae. Numerical pattern detection was undertaken. The results confirm our preliminary ideas that Blakea and Topobea do not differ enough to enable the separation of these genera on the basis of their wood anatomy. Within the Miconieae it is not possible to separate the genera. However, some anatomical differences between the two tribes were found. The genus Huilaea seems to belong in the Blakeeae although it also shows similarities with the Miconieae. Wurdack's suggestion (pers. comm.) that the Blakeeae are closest to the genera Loreya and Bellucia, and perhaps should be merged with the Miconieae, is supported to some degree.

\section{INTRODUCTION}

The present paper forms part of a project of an overall investigation into the comparative wood anatomy of the Myrtales. The greater number of families of the order is treated by VAN VLIET $(1975,1976,1978)$.

In the Section of Wood Anatomy of the Institute for Systematic Botany at Utrecht University the comparative anatomy of the neotropical Melastomataceae is under investigation (Ter Welle and Koek-Noorman). The Melastomataceae constitute a large, mainly tropical family of about 200 genera with c. 4500 
species, represented in Africa, Asia, Australia and particularly in America, where two thirds of the species are located (LANJOUw 1968). The family is divided into three subfamilies: Melastomatoideae, Astronioideae and Memecyloideae. The subfamily Melastomatoideae, at present under investigation, is composed of 11 tribes which occur chiefly in tropical America against the largely palaeotropical distribution of the other two subfamilies.

KRASSER's (1898) classification of tribes and genera is debatable in some parts, e.g. in the case of the Blakeeae. Wurdack, the present student of New World Melastomataceae, assigns the Blakeeae to a position near the Miconieae, in particular near Bellucia and Loreya (Wurdack, pers. comm.) He distinguishes two genera, Blakea and Topobea, whereas Krasser mentioned three genera: Blakea, Topobea, and Pyxidanthus. At present Blakea and Topobea comprise 92 and 66 species, respectively, all restricted to tropical South America and the Antilles. Another genus, Huilaea, was described by WURDACK (1957). He placed it in the tribe Miconieae, though a close resemblance with other genera in that group is absent. Floral characters are suggestive of a relation with Pachyanthus, Bellucia, and Loreya, and vegetative features point towards a relationship with Blakea and Topobea. Osejo (1966) mentions a resemblance in the inflorescences of Huilaea, Blakea, and Topobea. This paper reports on the wood anatomy of Blakea, Topobea, and Huilaea, and discusses the similarities and dissimilarities between them and a number of genera of the Miconieae. The complete wood anatomical descriptions of the latter genera will be published in another paper (Ter Welle \& Koek-Noorman, in prep.).

The structure of the vestured pits was studied in more detail with a scanning electron microscope (S.E.M.) and compared with VAN VLIET's classification (1978).

The similarity relations between the Blakeeae and Miconieae, as well as those between them and the genus Huilaea were further studied using numerical pattern detection techniques (section 5).

\section{MATERIAL}

All material used is now deposited in the wood collection in Utrecht (Uw). Part of it was made available to us by the kind co-operation of staff members of the Smithsonian Institution (Washington), the Forest Products Laboratory (Madison), the Commonwealth Forestry Institute (Oxford), the Jodrell Laboratory (Kew) and the Instituto de Ciencias Naturales (Bogotá).

\section{Specimens described and included in the pattern analysis:}

Bellucia acutata Pilger: Brazil - Uw 8174 (Krukoff 7093)

Bellucia axinanthera Triana : Brazil - Uw 17158 (Maguire et al. 51755)

Bellucia grossularioides (L.) Triana: Suriname - Uw 214 (Stahel 214)

Bellucia grossularioides (L.) Triana: Fr. Guyana - Uw 5602 (BAFOG 1082)

Bellucia imperialis Sald. et Cogn.: Suriname - Uw 4440 (Lindeman 6462)

Bellucia imperialis Sald. et Cogn.: Brazil - Uw 20045 (Krukoff 5580).

Blakea calyptrata Gleason:Colombia - Uw 22301 (USw 33077; Cuatrecasas 15535) 
Blakea latifolia (R. \& P.) D. don: Peru - Uw 22302 (USw 32559; Wurdack 1981)

Blakea paludosa Gleason: Peru - Uw 22275 (USw 15979; Woytkowski 5567)

Blakea pulverulenta Vahl.: Dominica - Uw 22276 (USw 35528; Stern \& Wasshausen 2488)

Calycogonium rhamnoideum Naud.: Cuba - Uw 22048 (FHOw 11637)

Charianthus alpinus (Sw.) Howard: Dominica - Uw 14757 (Wasshausen \& Ayensu 363)

Charianthus corymbosus (L.C. Rich.) Cogn. var. longifolius (Cogn.) Hodge: Dominica - Uw 15410

(USw 33942; Chambers 2557)

Clidemia bullosa DC.: Brazil - Uw 22052 (USw 17827; Harley 10699)

Clidemia dentata D. Don: Suriname - Uw 10095 (Schulz 9615)

Clidemia capitellata (Bonpl.). Don. var. dependens (D. Don) Macbride: Suriname - Uw 4249 (Lindeman 6206)

Conostegia montana (Sw.) DC.: Dominica - Uw 15401 (USw 33933; Chambers 2763)

Conostegia puberula Cogn. : Panama - Uw 22054 (FHOw 3588)

Conostegia cf. rufescens Naud.: Colombia - Uw 15729 (USw 38190; Fuchs 21770)

Conostegia xalapensis (Bonpl.) D. Don: Panama - Uw 14816 (USw 33731; Stern, Eyde \& Ayensu 1938)

Henriettea maroniensis Sagot: Suriname - Uw 3132 (Lindeman 4505)

Henriettea multiflora Naud.: Suriname - Uw 1300 (Lanjouw \& Lindeman 689)

Henriettea succosa (Aubl.) DC.: Suriname - Uw 4129 (Lindeman 6058)

Henriettella caudata Gleason: Suriname - Uw 2537 (Maguire 24821)

Henriettella caudata Gleason: Fr. Guyana - Uw 5726 (BAFOG 1237)

Henriettella cf. flavescens (Aubl.) Triana: Suriname - Uw 1730 (Lanjouw \& Lindeman 2413)

Henriettella sylvestris Gleason: Brazil - Uw 19865 (Krukoff 5272)

Huilaea macrocarpa Uribe ssp. minor Colombia - Uw 23622 (Lozano, Uribe, Diaz 2695)

Leandra barbinervis (Triana) Cogn.: Brazil - Uw 14545 (Reitz \& Klein 27747)

Leandra purpurascens (DC.) Cogn.; Brazil. - Uw 13388 (Lindeman \& de Haas 1889)

Leandra rufescens (DC.) Cogn.: Suriname - Uw 3953 (Lindeman 5799)

Leandra subseriata (Naud.) Cogn.: Colombia - Uw 15129 (USw 37358; King et al 5937)

Loreya acutifolia O. Berg ex Triana: Br. Guyana - Uw 930 (Br. Guyana 3314)

Loreya mespiloides Miq.: Suriname - Uw 3182 (Lindeman 4587)

Loreya quadrifolia Gleason: Brazil - Uw 19385 (Krukoff 1510)

Mecranium amygdalinum Wright apud Sauvalle: Cuba - Uw 22057 (FHOw 11638)

Miconia amplexans (Croeg.) Cogn.: Brazil - Uw 7604 (Krukoff 6264)

Miconia dodecandra (Desv.) Cogn.: Suriname - Uw 2538 (Maguire 24457)

Miconia eriocalyx Cogn. : Brazil - Uw 7768 (Krukoff 6498)

Miconia lateriflora Cogn.: Panama - Uw 22060 (FHOw 11626)

Miconia lepidota DC. : Suriname - Uw 223 (Stahel 223)

Miconia poeppigii Triana: Suriname - Uw 130a (Stahel 130a)

Miconia poeppigii Triana: Suriname - Uw 1442 (Lanjouw \& Lindeman 1287)

Myriaspora decipiens Naud.: Suriname - Uw 11099 (Florschütz \& Maas 2804)

Myriaspora egensis DC.: Brazil - Uw 7960 (Krukoff 6823)

Platycentrum clidemioides Naud.: Colombia - Uw 15227 (USw 37528; King et al 6228)

Tetrazygia bicolor (Mill.) Cogn.: U.S.A. - Uw 22063 (FHOw 12534)

Tetrazygia discolor (L.) DC.: Dominica - Uw 15405 (USw 33937; Chambers 2724)

Tococa egensis Naud.: Peru - Uw 22066 (FHOw 11632)

Tococa guyanensis Aubl.: Brazil - Uw 20049 (Krukoff 6823)

Tococa cf. longisepala Cogn.: Brazil - Uw 7505 (Krukoff 6135)

Tococa longisepala Cogn.: Brazil - Uw 7862 (Krukoff 6672)

Tococa subciliata (D.C.) Triana: Brazil - Uw 8092 (Krukoff 6998)

Topobea alternifolia Gleason: Colombia - Uw 22299 (USw 33222; Cuatrecasas 16585)

Topobea longiloba Wurdack: Colombia - Uw 22419 (USw 31736: Bristol 378)

Topobea membranacea Wurdack: Panama - Uw 22420 (USw 15645; Stern \& Chambers 175)

Topobea parasitica Aubl.: Brazil - Uw 16924 (Maguire et al. 48156)

Topobea praecox Gleason: Panama \& Canal Zone - Uw 22421 (USw 17170; Ebinger 258) 
Specimen described, but not included in the pattern analysis:

Blakea granatensis Naud. : Colombia - Uw 23623 (Idrobo, s.n.)

Specimens partly described, not included in the pattern analysis:

Blakea involvens Markgraf: Ecuador - Uw 23571 (Maas, Berg \& ter Welle 2902)

Blakea rosea (R. \& P.) D. Don: Venezuela - Uw 22277 (USw 25094; Maguire et al. 42079)

Specimens, obtained from herbarium vouchers, not included in the pattern analysis:

Blakea cf. pyxidanthus Triana: Colombia (Cuatrecasas 22175)

Topobea subbarbata Wurdack: Colombia (Cuatrecasas 22197)

Topobea subscaberula Triana: Colombia (Cuatrecasas 16602)

\section{LIGHT MICROSCOPICAL INVESTIGATIONS}

\subsection{Methods}

The wood samples were cut with a sledge microtome and thec. $15 \mu \mathrm{m}$ thick sections were stained with safranin. Length measurements of vessel members and fibres were made on macerated material, stained with astra-blue. Descriptions of the secondary xylem of Blakea, Topobea and Huilaea are given below. In the descriptions of Blakea and Topobea the lowest and highest average value of lengths, percentages, numbers and sizes, found in the specimens studied, are given.

In the description of Huilaea macrocarpa the average values for the single sample are given.

The averages of vessel member and fibre length, the number of vessels per sq. $\mathrm{mm}$., the number of rays per $\mathrm{mm}$, and the diameters were calculated from 20 , $25,20,25$, and 25 measurements, respectively.

For the measurement of ray height only the larger rays were taken into account.

The full range for all specimens is given between brackets.

\subsection{Descriptions}

3.2.1 Wood anatomy of Blakea (figs. 1,2)

Vessels: 7-19 (4-27) per sq.mm, diffuse, solitary (24-64\%) and in short radial multiples and scanty, irregular pore clusters. Perforations simple. Intervascular pits vestured, alternate, angular, round or oval, 8-15 $\mu \mathrm{m}$. Pores angular, round, or oval, diameter 75-151 (44-200) $\mu \mathrm{m}$. Vessel member length 453-750 (256-940) $\mu \mathrm{m}$. Vessel-ray pits round and oval $(5 \times 5$ to $4 \times 10 \mu \mathrm{m}$ ) and often oblong (up to $35 \mu \mathrm{m}$ long), mostly vestured.

Tracheids: not observed.

Fibres: septate, in some species both septate and non-septate. Cell walls $2-3 \mu \mathrm{m}$ thick. Lumen diameter up to 15-26 $\mu \mathrm{m}$. Pits simple, 2-3 $\mu \mathrm{m}$, on radial and tangential walls, in some species scanty or absent on tangential walls. Fibre length 626-1030(416-1355) $\mu \mathrm{m}$. Fibre/vessel member length ratio 1.25-1.38. Gelatinous fibres often present.

Rays: 1-2-seriate and often 3-4-seriate, composed of square and upright cells. Sheath cells present. Multi-seriate rays often vertically fused. Width up to 26-68 

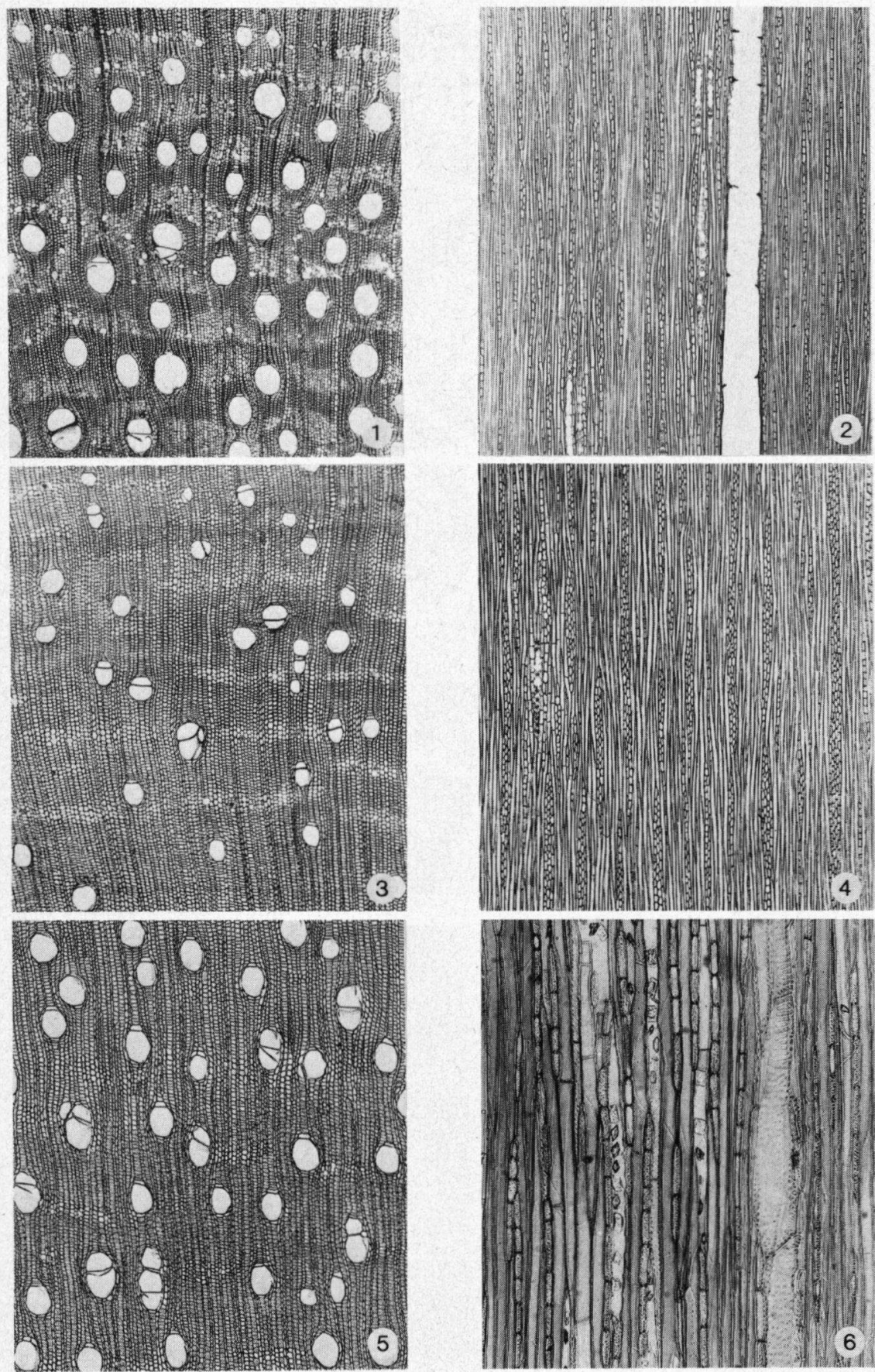

Fig. 1. Blakea granatensis Uw 23623: tranverse, $\times 45$

Fig. 2. Blakea calyptrata Uw 22301 ; tangential, $\times 45$

Fig. 3. Topobea praecox Uw 22421; transverse, $\times 45$

Fig. 4. Topobea parasitica Uw 16924; tangential, $\times 45$

Fig. 5. Huilaea macrocarpa Uw 23622; transverse, $\times 45$

Fig. 6. Huilaea macrocarpa Uw 23622; tangential, $\times 115$ 


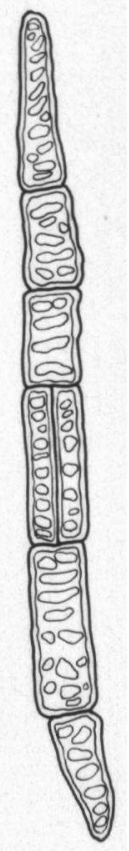

7
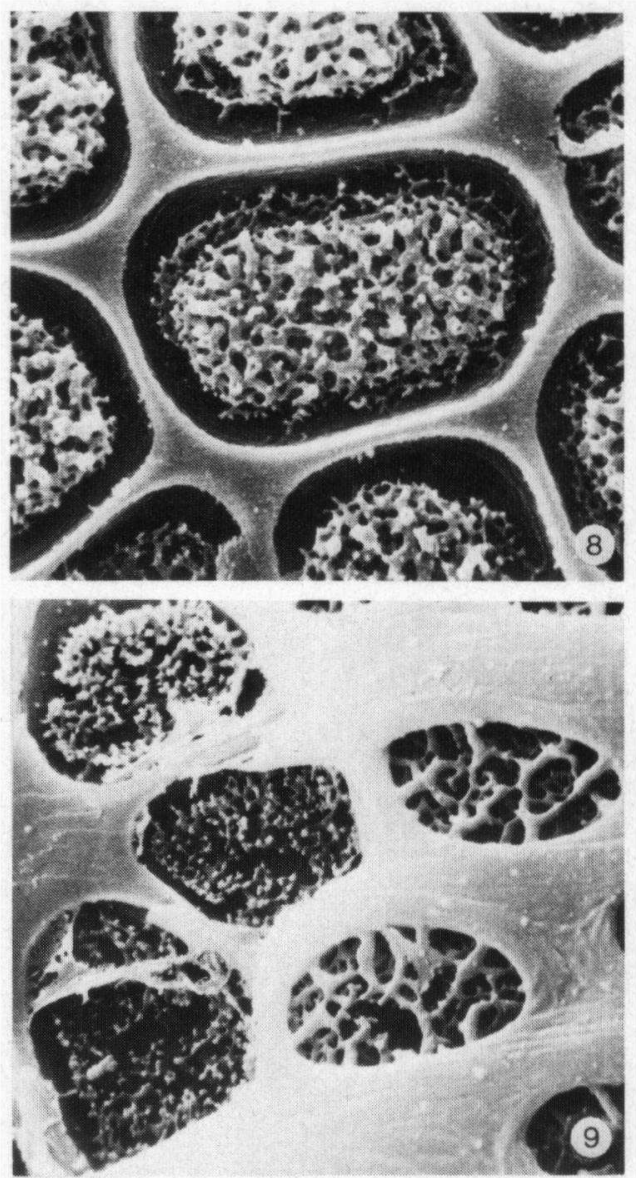

Fig. 7. Topobea praecox Uw 22421; parenchyma strand with subdivided cell. Fig. 8. Blakea paludosa Uw 22275; intervascular pits viewed from pit floor towards pit aperture. $\times \mathbf{4 6 0 0}$

Fig. 9. Topobea praecox Uw 22421; intervascular pits; the left ones viewed from pit floor towards pit aperture, the two right pits are viewed from the vessel lumen. $\times \mathbf{4 6 0 0}$ Fig. 10. Topobea praecox Uw 22421 ; druses in non-lignified parenchyma cells. $\times 900$.

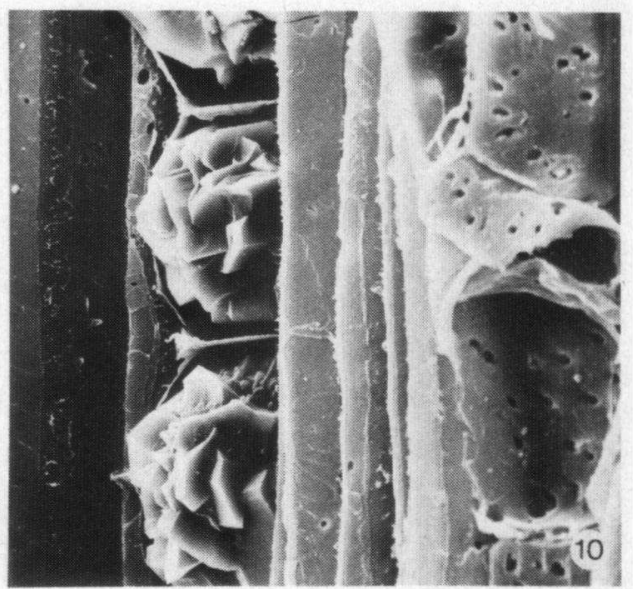


$\mu \mathrm{m}$, height up to $1150-2960 \mu \mathrm{m} ; 7-12$ (4-14) per mm.

Parenchyma: scanty paratracheal and in short apotracheal tangential bands, up to 10 cells wide, with intercellular spaces. Fusiform cells as well as strands of $2-4$ cells, some being idioblasts containing druses (fig. 10).

Notes on individual species:

Blakea calyptrata Gleason:

Pits absent on tangential fibre walls.

Blakea granatensis Naud.:

Parenchyma strands consisting of up to 16 cells.

Blakea latifolia (R. et P.) D. Don:

$11 \%$ of the vessels in irregular clusters; $3-4$-seriate rays, sheath cells, and vertically fused rays are lacking; diffuse apotracheal parenchyma strands are present, besides paratracheal strands and tangential bands; rhombic and elongated crystals occur, besides scanty druses.

Blakea paludosa Gleason:

Nearly all ray cells are upright, only few square cells occur.

Blakea pulverulenta Vahl:

The rays are composed of upright, square, and some procumbent cells.

\subsubsection{Wood anatomy of Topobea (figs. 3, 4)}

Vessels: 8-14 (3-20) per sq. mm, diffuse, solitary (38-52\%) and in short radial multiples and scanty irregular pore clusters. Perforations simple.

Intervascular pits vestured, alternate, angular or round, $8-12 \mu \mathrm{m}$. Pores round to oval, diameter 106-114 (44-196) $\mu \mathrm{m}$. Vessel member length 450-680 (176-832) $\mu \mathrm{m}$. Vessel-ray pits round and oval $(5 \times 5$ to $5 \times 8 \mu \mathrm{m})$ and often oblong (up to 25 $\mu \mathrm{m}$ long), some of them vestured.

Tracheids: not observed.

Fibres: both septate and non-septate. Cell walls $2-3 \mu \mathrm{m}$, lumen diameter up to 15-25 $\mu \mathrm{m}$. Pits simple, 2-3 $\mu \mathrm{m}$, on radial and less numerous on tagential walls. Fibre length 649-760(384-1008) $\mu \mathrm{m}$. Fibre/vessel member length ratio 1.15-1.50. Gelatinous fibres present.

Rays: 1-2-seriate and often 3-4-seriate, composed of square and upright cells. Sheath cells present. Multi-seriate rays often vertically fused. Width up to $30-56$ $\mu \mathrm{m}$, height up to $1920-4000 \mu \mathrm{m} ; 6-10(4-15)$ per $\mathrm{mm}$.

Parenchyma: in scanty paratracheal strands and short apotracheal tangential bands, up to 7 cells wide with intercellular spaces between the cells. Fusiform cells as well as strands of $2-8$ cells, some being idioblasts containing druses $(f i g .10)$. In some strands one or two cells are divided parallel to the longitudinal axis (fig. 7).

Notes on individual species:

Topobea alternifolia Gleason:

Vessel diameter $150(100-245) \mu \mathrm{m}, 25(20-30)$ per sq. mm. Gelatinous fibres absent. Rays composed of procumbent, square and upright cells. Parenchyma very abundant, reticulate and vasicentric, without intercellular spaces. Ray-vessel pits not observed. 
Topobea longiloba Wurdack:

Irregular pore clusters are scanty; in some vessels tyloses occur.

Parenchyma strands are not longer than 4 cells.

Topobea membranacea Wurdack:

All fibres are septate; gelatinous fibres are lacking.

Topobea parasitica Aubl.:

In the rays scanty procumbent cells occur.

Topobea praecox Gleason:

Irregular pore clusters are scanty; 3-4-seriate rays and sheath cells are lacking.

\subsubsection{Wood anatomy of Huilaea macrocarpa Uribe ssp. minor (figs. 5, 6)}

Vessels: $16(10-23)$ per sq. $\mathrm{mm}$, diffuse, solitary $(31 \%)$ and in short radial multiples and irregular pore clusters. Perforations simple.

Intervascular pits vestured, alternate, round and oval, $7 \times 7$ to $7 \times 10 \mu \mathrm{m}$. Pores angular and round, diameter $112(76-156) \mu \mathrm{m}$. Vessel member length 655 (383-1010) $\mu \mathrm{m}$.

Tracheids: not observed.

Fibres: both septate and non-septate, sometimes several septa per cell. Cell walls $4-5$ $\mu \mathrm{m}$ thick. Lumen diameter up to $15 \mu \mathrm{m}$. Pits simple, 2-3 $\mu \mathrm{m}$, on radial walls. Fibre length 952 (626-1224) $\mu \mathrm{m}$. Fibre/vessel member length ratio 1.46. Gelatinous fibres present.

Rays: exclusively uniseriate, except a few two-seriates, composed of predominantly upright and some square cells. Height up to $1300 \mu \mathrm{m} ; 10(7-14) \mathrm{mm}$.

Parenchyma: in scanty paratracheal strands and short apotracheal tangential bands, up to 3 cells wide, with many intercellular spaces between the cells. Strands of $2-4$ cells, the cells of ten containing elongated or rhombic crystals or druses, or intermediate forms.

\subsection{Discussion}

The descriptions of the Blakeeae contain a number of characters which are typical for the family of the Melastomataceae according to MetCalfE \& CHALK (1950). These characters are:

Vessels: solitary and in radial multiples; perforations simple; intervascular pits alternate, vestured; a verage length of the vessel elements $300-800 \mu \mathrm{m}$; on average 7-25 per sq. $\mathrm{mm}$.

Fibres: usually septate; pits simple.

Rays: mostly composed of upright and square cells.

Parenchyma: at least scanty paratracheal parenchyma present. Besides these characters, typical for the whole family, the Blakeeae show some characters by which they can be distinguished: druses in the parenchyma; multiseriate rays, often with sheath cells; rays often vertically compound; apotracheal parenchyma in short tangential bands.

Two specimens studied are deviating. The first one is a representative of Topobea alternifolia, a liana, which shows hardly any fibres but very abundant parenchyma. The average number of vessels per sq. $\mathrm{mm}$ is higher than in the other 
species and their average diameter is larger. The specimen corresponds to the other Blakeeae in the presence of druses and multiseriate rays. The other one is a specimen of Blakea latifolia. This specimen shows rhombic and elongated crystals as well as scanty druses. Sheath cells and vertically compound rays were not found. $B$. latifolia corresponds to the other Blakeeae in the presence of multiseriate rays and tangential bands of parenchyma.

In a final stage of this study additional, largely immature specimens of Blakea and Topobea became available (B. involvens, $B$. rosea, $B$. cf. pyxidanthus; $T$. subbarbata and $T$. subscaberula). In general these specimens were in close agreement with the species described here, except for $B$. cf. pyxidanthus which lacked druses in its xylem parenchyma. Sporadic absence of crystals in the wood of taxa for which they are generally diagnostic is, however, a well-known phenomenon in wood anatomy.

In some parenchyma strands of Topobea membranacea, $T$. parasitica and $T$. praecox cells subdivided parallel to the longitudinal axis, in radial direction, were observed. Curious is that, at least so far, this character has only been observed in specimens of these, according to Wurdack, closely related species of the genus Topobea.

As becomes clear from the descriptions above, there are no reliable differentiating characters between Topobea and Blakea.

However, VAN VLIET (1978) reports different types of vesturing in the closely allied Combretaceae. Therefore we then studied this character with a scanning electron microscope (S.E.M.) and compared the results with Van Vliet's data (see section 4).

The great homogeneity of the wood of the Blakeeae would seem to make it easy to distinguish them from the Miconieae, to which tribe the Blakeeae are considered to be closely related (see introduction). However, in spite of the great diversity in the wood anatomy of the Miconieae, it was impossible to indicate one or more genera with a good overall wood anatomical resemblance with Blakea and Topobea.

Huilaea constitutes another interesting problem in this respect ; although assigned to the Micronieae by WuRDACK (1957) its resemblance to Blakeeae has been emphasized (OSEJO, 1966) and is confirmed by the presence of crystals and tangential parenchyma bands.

Huilaea macrocarpa differs, however, from the Blakeeae by its exclusively uniseriate rays. In an attempt to arrive at a satisfactory interpretation of the wood anatomical diversity of the Miconieae, and of the systematic position of Huilaea and Blakeeae in relation to the Miconieae, a numerical analysis was applied (see section 5).

\section{S.E.M. INVESTIGATIONS OF PIT VESTURES}

\subsection{Methods}

Small wood samples of the Blakeeae and of a number of representatives of the Miconieae were treated for scanning electron microscopical examination. Unfixed 
specimens of these tribes at magnification of $\times 5000$ and more show a strong damage of the pits and their surroundings, due to an unknown cause. To overcome this problem a great number of fixation methods were tested. The best results are obtained when the samples were fixed in a $1 \%$ aquous solution of potassium permanganate during two minutes, rinsed in distilled water, dehydrated through a graded series of acetone and subjected to critical point drying in carbon dioxide in a Balzers critical point dryer. The samples were mounted on specimen stubs with silver paint and coated with a thin layer of gold.

\subsection{Results}

From photographs the intervascular pits were screened and were classified according to VAN VLIET (1978). He distinguishes two main types of vesturing, type $A$ and $B$. Type $B$ is subdivided in $B_{1}, B_{2}$ and $B_{3}$. The classification is based on the way in which the vestures are attached to the roof of the pit chambers and the degree of branching of the vestures.

Using van Vliet's classification of vesture types we found the following results:

Type A

Blakea granatensis

Blakea latifolia

Blakea paludosa

Clidemia dependens

Henriettea maroniensis

Henriettella caudata

Miconia plukenetii

Tococa guianensis

Tococa longisepala
Type A+B $\quad$ Type B

Blakea calyptrata

Blakea pulverulenta

Bellucia acutata

Bellucia axinanthera

Huilaea macrocarpa

Tessmanianthus calcaratus

Topobea alternifolia
Charianthus coccineus

Charianthus corymbosus

Henriettea multiflora

Loreya acutifolia

Loreya quadrifolia

Topobea longiloba

Topobea membranacea

Topobea preacox

In Topobea parasitica vesture types $\mathrm{B}_{1}$ and $\mathrm{B}_{2}$ were observed.

\subsection{Discussion}

The two major types of vesturing of the bordered pits as recognized and described by VAN VLIET (1978) are present in the Miconieae and Blakeeae. Van Vliet also reported these types $A$ and $B$ in the Melastomataceae.

It is not possible to distinguish the Miconieae from the Blakeeae on the basis of the structure of the vesturing of the pits. In both tribes both types occur as well as intermediate forms. In the tribe Blakeeae, however, Topobea and Blakea can be separated to a certain extent because Blakea shows vestures of type $A$ and in some species a transition to type $B_{1}$, while in Topobea only type $B_{1}$ occurs (in $T$. parasitica even grading to type $B_{2}$ ).

Intermediate forms prevent, however, a clear distinction between the two genera. 
5. NumERiCal PATTER ANALYSIS OF THE DATA SET OF WOOD

ANATOMICAL CHARACTERS OF BLAKEEAE AND MICONIEAE

\subsection{Methods}

Introduction. In pattern analysis, as performed in systematic taxonomic studies, we may distinguish the following steps:

I. description of the specimens

II. pattern detection in sets of specimens ('classification')

III. description of classes (taxa)

IV. pattern recognition s.s. (e.g. construction of determination keys)

Steps II and III provide an extensive and intensive definition of the classes respectively. As argued by HoGEWEG $(1976 \mathrm{a}, \mathrm{b})$ applying these steps iteratively may lead to pattern enhancement. Such pattern enhancement is common in classical systematic studies and was defined in an exact form which rendered it accessable for numerical analysis by HOGEWEG (1976b), and was applied in wood anatomical context by HoGEWEG \& KOEK-NOORMAN (1975).

The methods chosen for each of the above mentioned steps (including pattern enhancement) in the present study are detailed below. All analyses were performed by 'BIOPAT', program system for biological pattern analysis (HOGEWEG \& HESPER, 1972).

\section{Description of specimens}

The list of features used in our previous analysis of wood anatomical data (KOEKNOORMAN \& HOGEWEG 1975) was used here again. This list had been compiled using previous experience, but was modelled to fit especially the Rubiaceae. Nevertheless we could use the list for an adequate description of the present specimens with only minor modifications. Instead of the characters $70-73$, the following features were used:

ray-vessel pitting: $70^{\prime}$. similar to intervascular pitting $71^{\prime}$. oval-reticulate, the longest axis

$\begin{array}{lrrr} & <10 \mu \mathrm{m} & 0 & 1 \\ & 10-20 \mu \mathrm{m} & & 2 \\ & >20 \mu \mathrm{m} & 3 \\ 72^{\prime} \text {. scalariform } & & 0 & 1 \\ 73^{\prime} \text {. pits vestured } & & 0 & 1\end{array}$

\section{Pattern detection}

Agglomerative cluster analysis was used augmented with techniques for optimal subdivision of a dendrogram in clusters and with iterative replacement techniques of cluster analysis to identify specimens whose assignment to a class was due to local rather than global characteristics of state space.

a. Agglomerative cluster analysis

- similarity criterion: mean character differences on normalised data.

- clustering criterion: minimisation of increase of mean square error (WARD 1963; WISHART 1969). 
For a rationale of the choice of these criteria (and the combination) see HOGEWEG 1976a, b.

\section{b. Optimal subdivision of the dendrogram into clusters}

To make the results of an agglomerative cluster analysis (a dendrogram) amenable for further analysis we often wish to subdivide it into clusters. Although in a heuristic method, as is cluster analysis, any subdivision of the dendrogram is allowable, the robustness of further processing methods may be crucially dependent on the optimality of the choice of the level of subdivision (e.g. in case of iterative replacement cluster analysis). Optimal splitting levels were computed according to the criterion of HoGEWEG (1976b), which compares locally within and between cluster ultrametric distances.

c. Iterative replacement cluster analysis

Starting with the clusters as found by the methods mentioned in $a$ and $b$, iterative replacement techniques were applied to identify discrepances in cluster assignment between the local technique of agglomerative cluster analysis and the more global definition of clusters in these techniques. As criterion again minimisation of mean square errors was used (WARD 1963; WiShaRT 1969). Almost no discrepances were found.

\section{Cluster description}

Primary statistics of the characters in the clusters (mean, standard deviation and frequency) were used as initial description of the clusters. 'Importance of characters' for a classification was assessed by Kruskal Wallis one way analysis of variance used as index, that is to say the ill-defined concept of importance of characters was refined as to mean the extent to which character rankings were unevenly devided among (extensively defined) clusters.

The iterative character weighing technique of pattern enhancement consists of alternating extensive and intensive definitions of classes, i.e. applying step II and III iteratively; starting with equally weighted characters an agglomerative cluster analysis is performed and the characters are subsequently weighed according to their importance in the current classification (as defined in step III above) and using these weights a new agglomerative cluster analysis is performed, yielding a different classification and consequently different character weights. This process is iterated while forcing the optimality criterion for splitting the dendrogram to select an ever larger number of clusters. (see HOGEWEG 1976 b, HOGEWEG \& KOEKNOORMAN 1975).

The results of this iteration are here represented by a density print of the similarity matrix, ordered to fit the dendrogram (fig. 11a,b,c). By overprinting a darkness scale is constructed so that the similarity (and difference in similarity) is easily observed (the darker the more similar, i.e. the smaller the distance). This representation shows clearly that in our case the initial classification is rather 'fuzzy', as specimens belonging to different clusters frequently exhibit a high similarity. Character weighing and replacement of specimens finally results in a similarity table which exhibits the clusters very clearly. 


\section{Pattern recognition s.s.}

Oligothetic recognition

Most often classifications found in systematic studies (whether numerical or not) are very 'redundant', i.e. only a fraction of the characters used for pattern detection (the construction of a classification) is used for the description of classes, while for the recognition of classes again only a fraction of the characters used in the description of the classes is needed.

Recognition criteria for the clusters were generated in this study using an oligothetic discrimination method as implemented in CLASER, which minimises classification errors while using a small number of the characters only (HOGEWEG 1978). The method generates a selection of characters (in most applications a drastic reduction of the number of characters, in our case to 8 out of 125) and a quadratic discriminant function for assigning specimens to the groups. A specimen belongs to the group $i$, if

$\mathrm{D}_{i}=\Sigma_{j=1}^{n}\left(-\mathrm{a}_{j} \mathrm{v}_{j}+\mathrm{b}_{j} \mathbf{v}_{j}^{2}\right)+\mathrm{c}$

is minimal; where $\mathrm{n}=$ number of selected characters, $\mathrm{a}_{j}=$ liniar coefficient for character $j, b_{j}=$ quadratic coefficient for character $j, v_{j}=$ value for character $j$ in the specimen to be classified, and $c=$ constant. It should be noted that the method slightly favors the use of quantitative characters, because they can contain more information. Nevertheless qualitative characters were selected in this case.

Polythetic recognition and projection

Besides the oligothetic technique mentioned above, which provides an easy recognition criterion, a polythetic method was used to obtain an insight in the relations between the clusters by projecting them into a two-dimensional space, so that cluster differences are optimally represented (by maximizing between cluster distances while keeping total distances constant; SEBESTEYN 1962).

\subsection{Results}

Initially all features were given equal weight. Agglomerative cluster analysis according to criteria mentioned above resulted in the dendrogram shown in fig. $11 a$, which is optimally subdivided into two clusters.

The extensive definition of the clusters (as given in the dendrogram labelling, fig. 11a) shows that cluster 2 consists exclusively of specimens of the Blakeeae and contains 8 out of the 9 investigated specimens of this tribe. Cluster 1 consists of the investigated specimens of the Miconieae and of Blakea latifolia and the only representative of the genus Huilaea; the latter two specimens are grouped close together. In both clusters specimens of the same genus are scattered throughout the cluster.

Characters of which the distribution differs strongly between the two clusters (i.e. are 'important' for this classification) include:

- the size of the intervascular pits ( $>8 \mu \mathrm{m}$ in cluster 2 versus $5-7 \mu \mathrm{m}$ in cluster 1 ),

- presence of sheath cells (always present in cluster 2 , never in cluster 1 ),

- two-seriate rays (in $50 \%$ combined with 3-4-seriate rays in cluster 2 versus only 1 -seriate rays in almost all specimens in cluster 1$)$.

- the size of the ray-vessel pits ( $>20 \mu \mathrm{m}$ in cluster 2 versus $<20 \mu \mathrm{m}$ in cluster 1 ). 


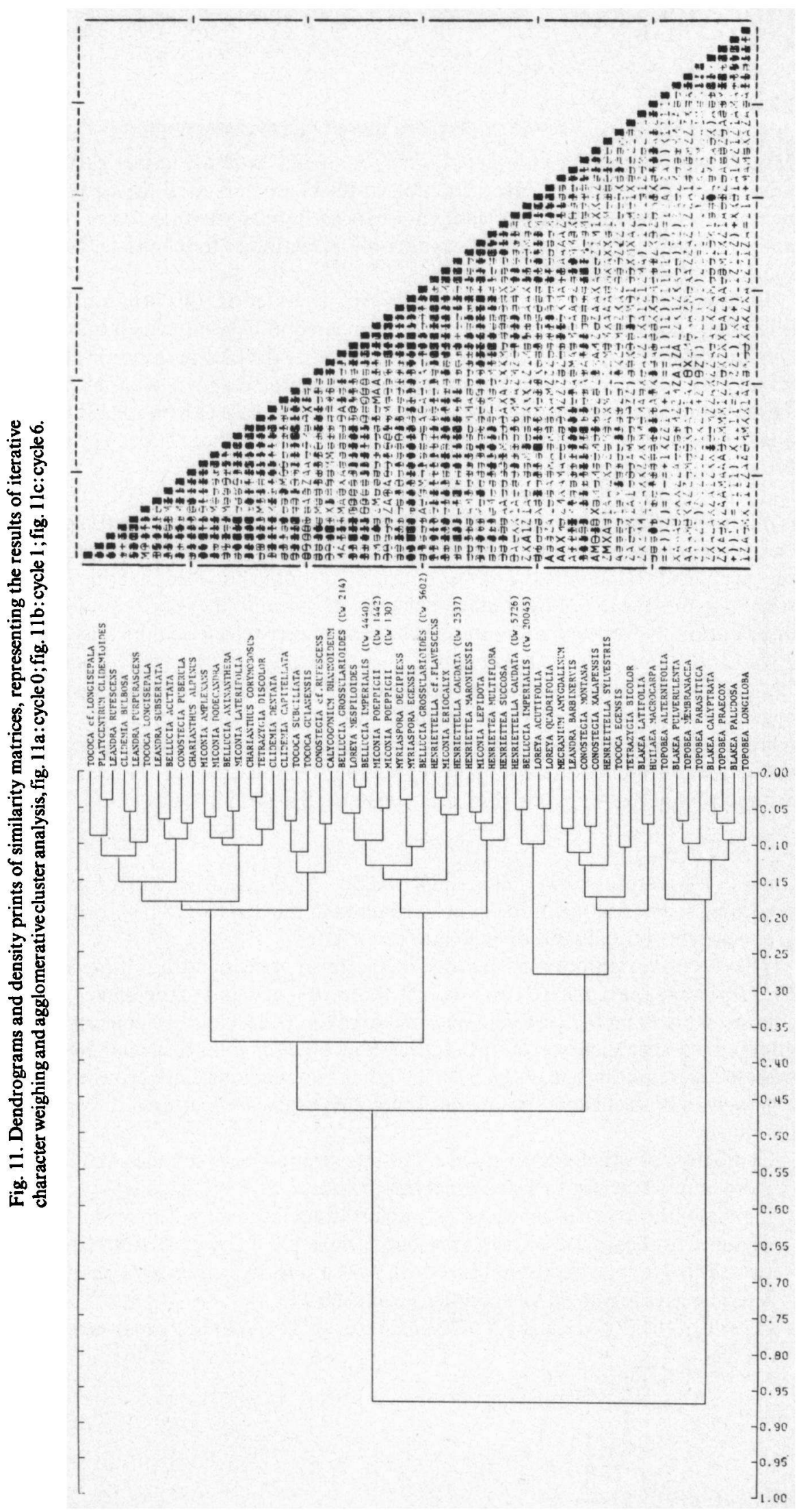




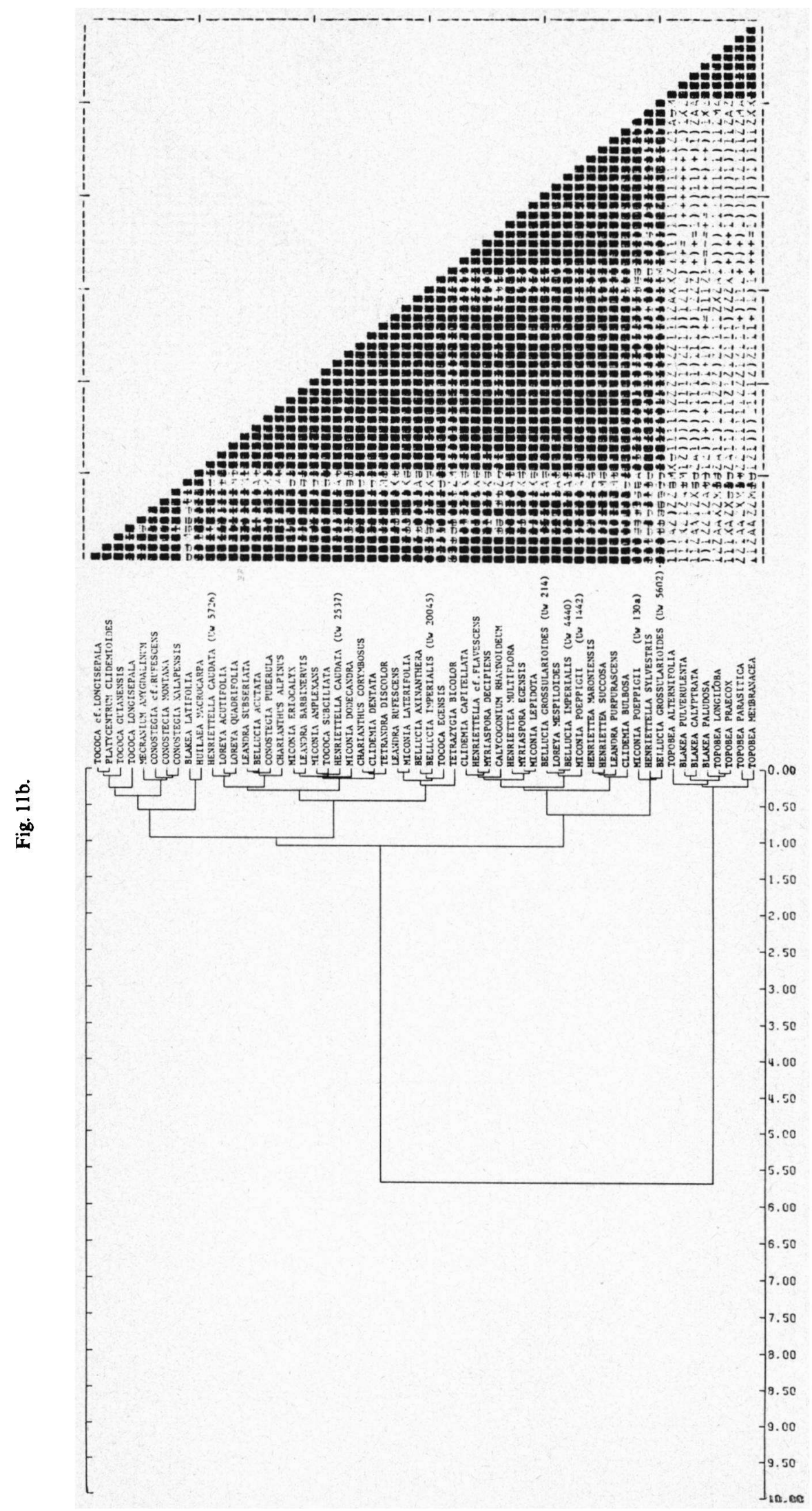




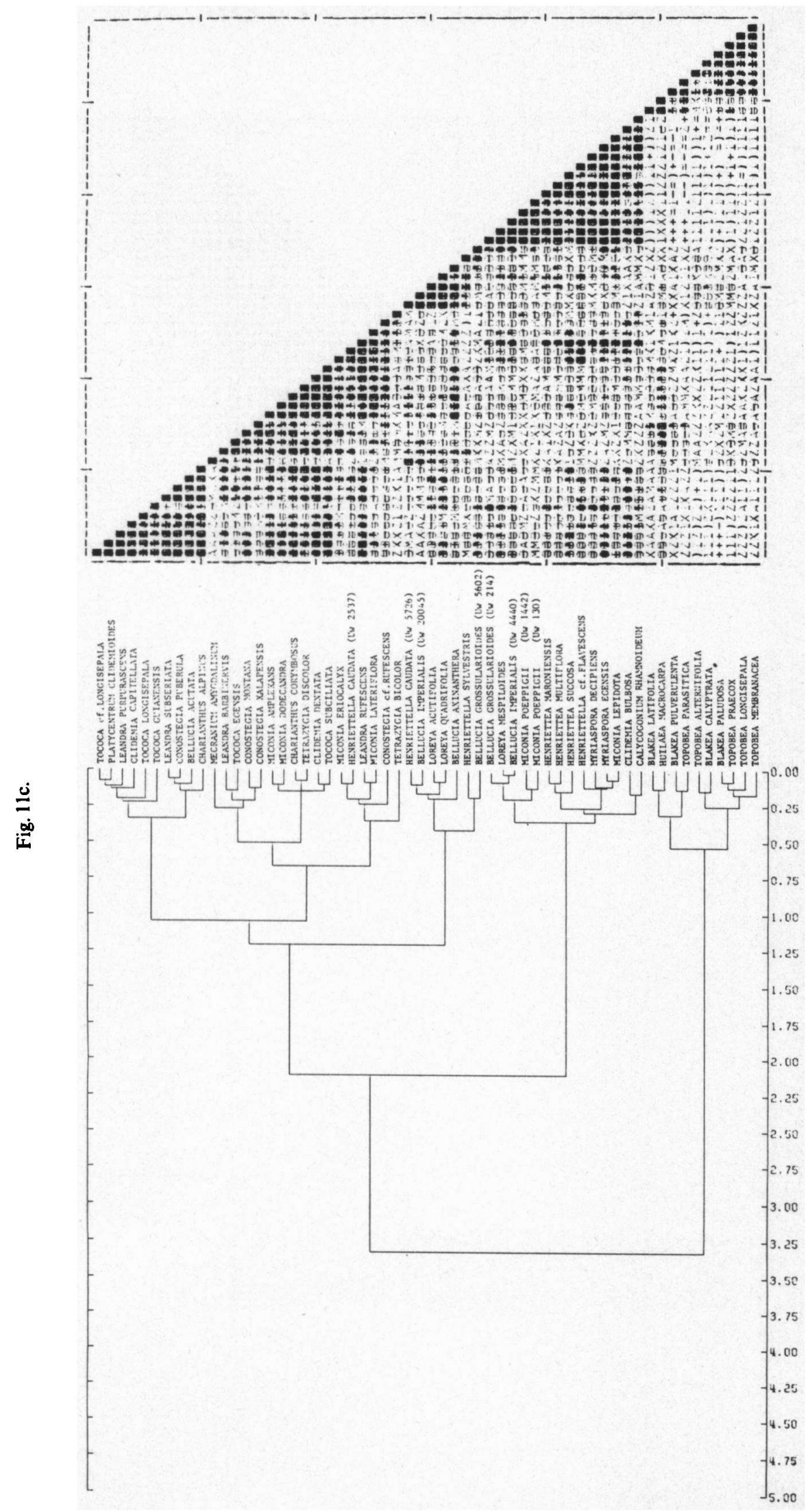


- the presence of crystals (druses always in cluster 2, rarely in cluster 1),

- short tangential parenchyma bands (nearly always present in cluster 2, mostly absent in cluster 1 ).

Recognition of the clusters can be done on one single character, i.e. the presence of sheath cells; these are always present in cluster 2 and never in cluster 1 . Note that Blakea latifolia and Huilaea macrocarpa differ in this respect from the Blakeeae of cluster 2.

Other than the optimal subdivision into two clusters, the structure of the data set is rather weak, as can be seen in fig. 1la: the similarity matrix does not clearly show the clusters; the forks of the dendrogram are all of similar length and the genera are scattered throughout the clusters. Therefore an attempt to pattern enhancement through iterative character weighing was undertaken.

The results are shown in fig. $11 a, b, c$, for the initial, first and sixth (final) iteration cycle. We note that:

The cluster structure has become more pronounced, starting with a subdivision into two clusters in the initial and more pronounced in the first iteration cycle, towards an optimal subdivision into 5 clusters in the final iteration cycle (after

Table 1. Selected features for recognition of all clusterings generated during the iteration. $100 \%$ correct classification was obtained in all cases.

\begin{tabular}{lllllllll}
\hline Character & 0 & 1 & 2 & 3 & 4 & 5 & 6 & cycle \\
& $(2)$ & $(6)$ & $(7)$ & $(8)$ & $(9)$ & $(10)$ & $(5)$ & (optimal number of clusters)
\end{tabular}

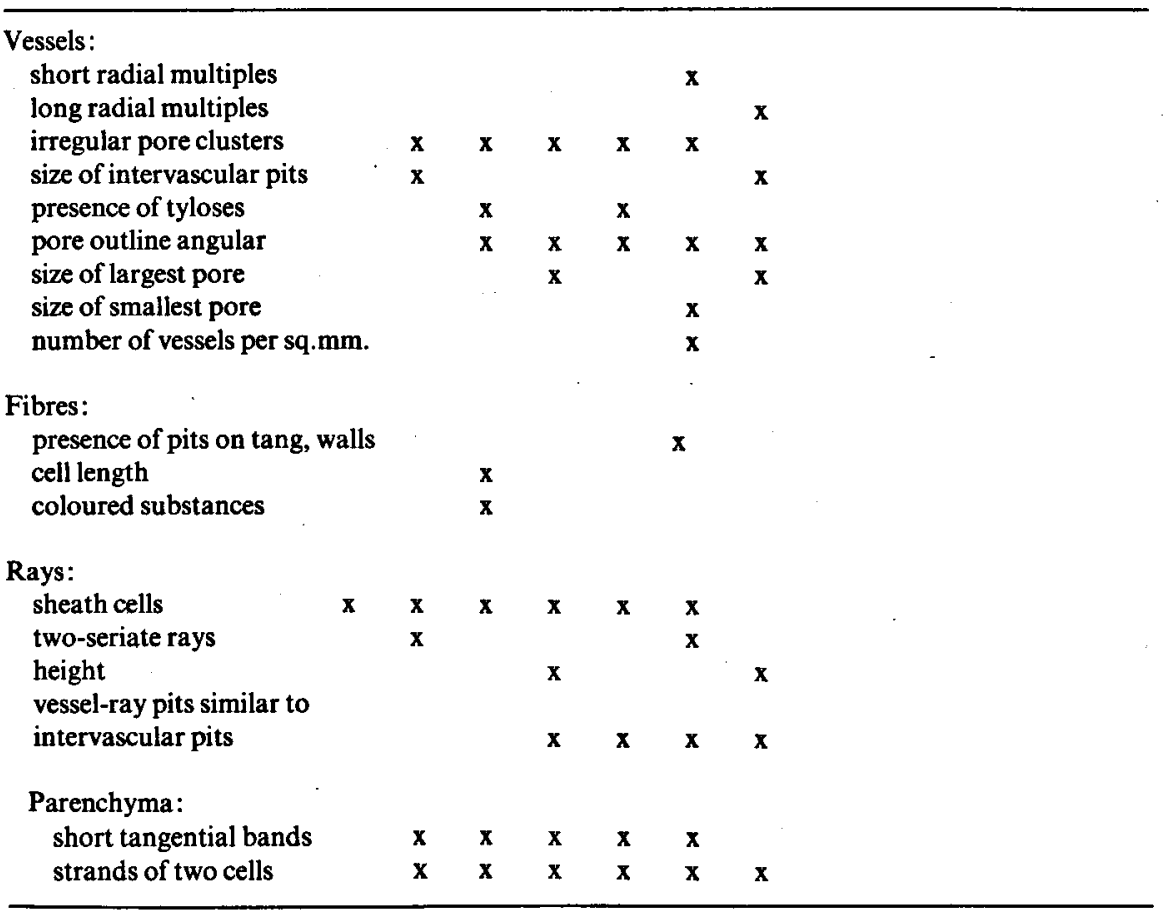


weighing on the basis of ten clusters in the fifth cycle). Although most genera remain scattered, nearly all are confined to only one or two of these five clusters. Most remarkable is the fact, that Blakea latifolia and Huilaea macrocarpa join the Blakeeae cluster in this final iteration. In all previous cycles they remain in the Miconieae clusters, showing a high degree of resemblance to some specimens of Conostegia but a low resemblance to all other specimens in those clusters. When they finally join the Blakeeae cluster they show a high degree of similarity to Blakea pulverulenta and Topobea parasitica, but rather less resemblance to the other members of this cluster.

Focussing on the subdivision into two clusters in $\mathrm{fig} .11 \mathrm{c}$, i.e. the Miconieae versus the Blakeeae, including Huilaea macrocarpa, and the distribution of the features among these two clusters, we see that our importance measure has increased for almost all features, in particular for:

- the size of the intervascular pits

- the size of the largest pores

- the number of rays per $\mathrm{mm}$.

- the size of the ray-vessel pits

- the presence of short tangential parenchyma bands

- the presence of crystals (druses).

Table 2. Quadratic discriminant functions for 5 final clusters (fig. $11 \mathrm{c}$ ).

\begin{tabular}{lccccc}
\hline & cluster 1 & cluster 2 & cluster 3 & cluster 4 & cluster 5 \\
\hline$a_{16}$ & -63.10 & -53.00 & -52.32 & -38.24 & -77.21 \\
$a_{24}$ & -23.32 & -21.43 & -0.00 & -3.20 & -6.01 \\
$a_{96}$ & -0.00 & -74.27 & -3.59 & -0.00 & -74.27 \\
$a_{70}$ & -0.00 & -4.46 & -0.00 & -55.69 & -0.00 \\
$a_{44}$ & -1.35 & -3.70 & -1.75 & -3.83 & -7.31 \\
$a_{3}$ & -0.50 & -0.48 & -0.00 & -0.00 & -0.00 \\
$a_{69}$ & -43.09 & -21.50 & -54.98 & -44.80 & -51.68 \\
$a_{28}$ & -81.70 & -37.36 & -79.13 & -32.44 & -93.87 \\
const. & 216.97 & 171.38 & 283.64 & 174.19 & 415.29 \\
& & & & & \\
$b_{16}$ & 16.61 & 12.87 & 10.77 & 10.30 & 11.70 \\
$b_{24}$ & 12.96 & 12.15 & 22.93 & 11.20 & 7.51 \\
$b_{96}$ & 37.14 & 37.14 & 3.59 & 37.14 & 37.14 \\
$b_{70}$ & 27.85 & 6.31 & 27.85 & 27.85 & 27.85 \\
$b_{44}$ & 6.77 & 4.49 & 6.11 & 4.47 & 4.06 \\
$b_{3}$ & 0.50 & 1.35 & 2.62 & 2.62 & 2.62 \\
$b_{69}$ & 7.18 & 3.97 & 7.13 & 7.13 & 6.63 \\
$b_{28}$ & 20.43 & 8.82 & 13.85 & 6.68 & 15.14
\end{tabular}

Feature 16 : size of intervascular pits; 24 : pores angular ; 96 : parenchyma strands of 2 cells; 70 : rayvessel pits similar to intervascular pits; 44 : pits present on tangential fibre walls; 3 : vessels in long radial multiples; 69 : height of rays; 28 : size of largest pores.

A specimen belongs to cluster $i$ if $D_{i}$ is minimal. $D_{i}=\Sigma_{j=1}^{n}\left(-a_{j} v_{j}+b_{j} v_{j}^{2}\right)+c$ 
An important exception is formed by the presence of sheath cells, which are not invariably present in cluster 2 anymore.

The distribution of multiseriate rays remains about the same, as Blakea latifolia does agree, contrary to Huilaea macrocarpa, with the other Blakeeae for this feature. The same is true for the presence of pits on the tangential fibre walls; they occur more frequently in the Blakeeae than in the Miconieae, are present in Blakea latifolia, but absent in Huilaea macrocarpa.

Table 1 shows the results for the oligothetic recognition of the clusterings obtained during the iteration. All clusterings could be recognised using at most 8 features. The selected features do, of course, change during the iteration (because of several reasons, e,g. replacement of specimens, a changing number of clusters, and redundancy). Nevertheless only 18 features in total were needed for correct classification of the specimens in all stages of the iteration. This result shows clearly, that, even if polythetic methods are used for obtaining a classification, oligothetic description and recognition remains possible (note, that this is a property of the data set, not of the methods). The discriminant functions for the final 5 clusters is shown in table 2.

In order to obtain an insight into the non-hierarchial relations between the 5 clusters, they were optimally projected into two dimensions, maximizing between cluster distances while keeping the total distances the same. The result for the five clusters of the final iteration cycle is shown in fig. 12. The horizontal axis (1) separates the Blakeeae from the Miconieae. Huilaea macrocarpa and Blakea latifolia to a lesser degree are seen as intermediate between these two groups. Features important for this axis are those already mentioned above as distinguishing these two groups. The second axis separates the clusters 1 and 2 (negative on this axis) from the clusters 3 and 4 (positive on this axis). The clusters 1 and 2 contain, amongst others, the specimens representing Conostegia, tentatively placed on one side of a 'possible morphological sequence' given by Wurdack (pers. comm.). The clusters 3 and 4 contain e.g. Bellucia and Loreya, which genera are placed far from Conostegia in Wurdack's series.

Most of the Blakeeae are also on the positive side of this axis (exceptions again Blakea latifolia and Huilaea macrocarpa). Features with high weights on this axis include:

- angular pores and oval pores

- the number of vessels per sq.mm.

- fibres all septate

- the presence of coloured substances in the vessels

- ray-vessel pits vestured

- parenchyma strands of two cells

- the presence of growth rings

\subsection{Discussion}

\section{Polythetic, monothetic and oligothetic classifications}

There has been a long standing discussion on the aims and methods of systematic taxonomic studies. One of the issues concerns polythetic versus monothetic classifications (Adanson 1763, versus De Candolle 1813; Sokal \& SNEATH 1963).

The present study shows how to interrelate the diverse standpoints: Initially one starts to take all available information into account, and arrives at a classification in which only a few features prove to be important for the description of the 
classes and even less features are needed for the recognition of the classes (i.e. determination of the specimens). Optionally one can try to enhance the pattern by weighting the so found 'important' features. In any case the final results are in the form of an oligothetic classification although this selection of features does not suffice to generate the classification.

\section{Blakeeae and Miconieae}

The numerical analysis shows that the investigated specimens of the Blakeeae

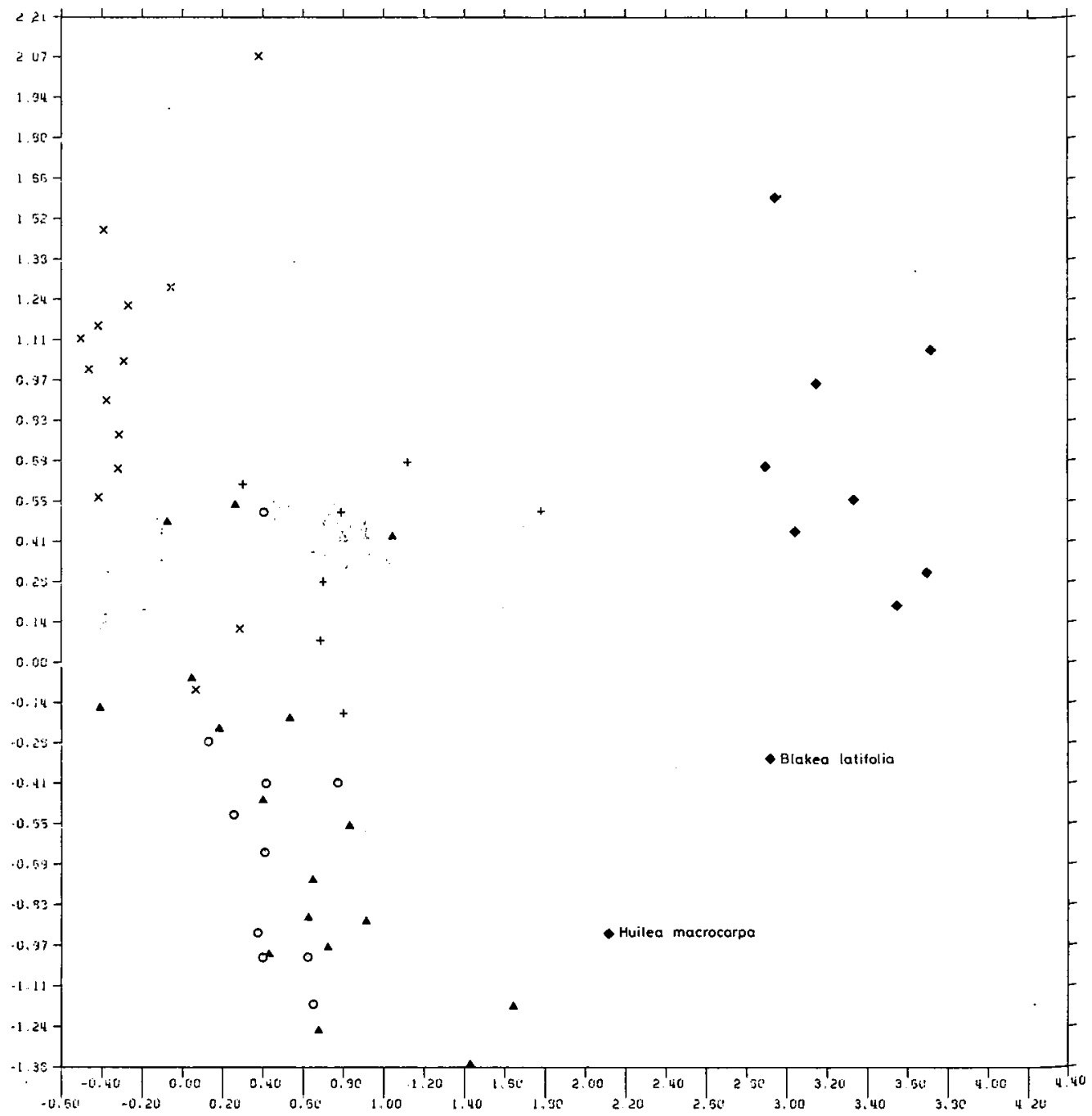

Fig. 12. Projection of the optimal clusters of fig. 11c. o: cluster $1 ; \Delta$ : cluster $2 ;+:$ cluster $3 ; \times$ cluster 4 ; : cluster 5 . 
differ considerably from those of the Miconieae and thus supports the distinction of these two tribes. The one 'misclassification', i.e. Blakea latifolia which is classified in the Miconeae cluster is partly due to its aberrant structure (in particular the absence of sheath cells) and partly due to its resemblance to Huilaea. The position of the latter genus is ambiguous, both in our analysis and according to the literature on the subject (OSEJo 1966). As described above, during the iterative character weighing both Huilaea and Blakealatifolia remain for a long time within the Miconieae cluster, showing a high degree of resemblance with some specimens but a low degree of resemblance for all other specimens of the group. Only in the final iteration they join the Blakeeae cluster. The final Blakeeae cluster (including Blakea latifolia and Huilaea) is less easily recognizable than the initial Blakeeae cluster (especially in the oligothetic approach, where not only sheath cells are needed (cf. the initial cycle) but all characters, mentioned for the recognition of 5 final clusters, are (table I, last column). However, as mentioned above the distribution of quite a few features becomes more pronounced in the latter classification. For a final assessment of the position of Huilaea a more thorough study of more specimens of Huilaea is needed. The wood anatomical distinction of the Blakeeae without Huilaea is, however, clearcut: they can be recognized on a combination of two characters: the presence of sheath cells and/or the presence of many pits on tangential fibre walls.

The question as to which subgroup of the Miconieae resembles most the Blakeeae has been put forward by Wurdack, and he mentions the genera Bellucia and Loreya as such. Our analysis (see fig. 12) shows that:

1. as far as the differences between Blakeeae and Miconieae are concerned (horizontal axisin fig. 12) the subgroup of the Miconieae clustered in the clusters 1 and 2 resembles the Blakeeae most. This agrees with the fact that Blakea latifolia and Huilaea are classified there initially, and

2. as far as the major other differences (vertical axis in fig. 12) are concerned the Blakeeae resemble mostly cluster 3 and 4 , i.e. those of Bellucia and Loreya.

Thus our analysis agrees with Wurdack's conjecture in the following way: If we decide to ignore the differences between Miconieae and Blakeeae (i.e. ignore the first axis) the Blakeeae resemble the genera Bellucia and Loreya most.

\section{Conclusions}

Initially studying the wood of the Blakeeae and Miconieae, we were struck by the frequent occurrence of druses in the parenchyma of the Blakeeae and wondered whether this feature could form a differentiating character between Blakeeae and the closely related Miconieae. MetCalfE \& CHALK (1950) mention the absence of crystals in the wood of the Melastomataceae. However, besides in the samples of the Blakeeae, crystals were observed in Huilaea macrocarpa, Tococa longisepala* (Uw 7862), Henriettea maroniensis, and Henriettea succosa. The styloid crystals reported from the latter two (TER WELLE \& MENNEGA 1977) appeared to be of

* It is rather disturbing that no crystals were found in Uw 7505, another sample of this species which, however, was labelled with some hesitation Tococa cf. longisepala. 
minor importance in the numerical analysis, since during the proces of weighing the specimens sometimes appeared together and sometimes in different clusters. Druses and elongated crystals, restricted to the Blakeeae Huilaea macrocarpa and Tococa longisepala, contribute considerably to the subdivision into Blakeeae and Miconieae.

Because of the exceptions formed by Tococa and Henriettea, crystals do not play a role in the oligothetic recognition (table 1).

The wood of another species of Blakea, B. granatensis, was received too late for computer analysis, but as the sample resembles the other Blakeeae in all important and differentiating characters, it seems justified to assume that this species could also be placed in cluster five.

The tribe of the Miconieae even after iterative weighing remains a complex group. From the scattered distribution of the genera over the clusters 1, 2, 3, and 4, it is clear, how difficult it is to recognize genera of the Miconieae by their wood structure.

Taking into account the restricted material of the various genera available for investigation and the variation that was occasionally found between samples of one species, we think, that the following conclusion may be drawn. At least a number of important structural features of Blakeeae and Miconieae differ sufficiently to maintain these tribes.

The genus Huilaea is better placed in the Blakeeae in spite of similarities with some representatives of the tribe Miconieae. Wurdack's suggestion (pers. comm.) that if the Blakeeae tribe were to be merged with the Miconieae, the genera of the Blakeeae should be placed near Bellucia and Loreya, is supported to a certain extent by our results, as is shown in fig. 12 .

However, when we compare the features important for axis 1 and 2 in fig. 12, the combination of features contributing to axis 1 seem to us to be of more 'taxonomic value' because of their relatively higher constancy in a wide variety of taxa.

\section{ACKNOWLEDGEMENTS}

A grant from the Miquel Fonds enabled one of us (B. J. H. TER WeLLE) to make a field trip to Ecuador and Suriname, during which he collected part of the material studied. The scanning electron microscope was operated by dr. W. Berendsen (Utrecht, Institute for Electron Microscopy). We gratefully acknowledge his interest in this study. Messrs. A. Kuiper and T. Schipper prepared the illustrations. Mrs. J. Hendriks-Holla and Mrs. R. de Rooy-Stekelenburg diligently typed the manuscript. Thanks are due to $\mathrm{mr}$. L. Y. Westra for correcting the English text.

\section{REFERENCES}

Adanson, M. (1763): Familles des plantes, vol. 1, Preface. Vincent, Paris.

CANDOLle, A. P. DE (1813): Théorie elementaire de botanique, ou exposition des principes de la classification naturelle et de lart de décrire el d'étudier les végétaux. Déterville, Paris.

HOGEWEG, P. \& B. HESPER (1972): BIOPAT, program for biological pattern analysis, Bioinformatie, RU Utrecht.

-\& J. KOEK-NOORMAN (1975): Wood anatomical classification using iterative character weighing, Acta Bot. Neerl. 24 : 269-283. 
- (1976a): Topics in Biological pattern analysis. Thesis, Utrecht.

- (1976b): Iterativecharacter weighing in Numerical Taxonomy. Computers in Biology and Medicine 6: 199-211.

- (1978): Oligothetic characterisation of clusters, in prep.

Krasser, F. in A. Engler \& K. Prantl (1898): Die natürlichen Pflanzenfamilien. III (7). Leipzig. LaNjouw, J. (ed.) (1968): Compendium van de Pteridophyta en Spermatophyta. Oosthoek, Utrecht. Metcalfe, C. R. \& L. ChalK (1950): Anatomy of the Dicotyledons I. Clarendon Press, Oxford.

OSEJO, L. E. M. (1966): Contribuciones al Conocimiento de la Morfologia comparada de las Inflorescencias y de las Formas de Crecimiento de las Melastomataceae, 1. Inflorescencias de Huilaea, Topobea y Blakea. Caldasia 9 (44): 303-312.

SEBESTEYN, G. S. (1962): Decision making Processes in pattern recognition. MacMillan, New York.

SOKAL, R. R. \& P. H. A. SNEATH (1963): Principles of Numerical Taxonomy. W. H. Freeman and Co, San Francisco.

VLIET, G. J. C. M. VAN (1975): Wood anatomy of Crypteroniaceae sensu lato. J. Micr. $104:$ 65-82.

-(1976): Wood anatomy of Rhizophoraceae. Leiden Bot. Ser. 3: $20-75$.

- (1978): Vestured pits of Combretaceae and allied families. Acta Bot. Neerl. 27: 273-285.

WARD, J. H. (1963): Hierarchial grouping to optimise an objective function, J. Amer. Stat. Ass. 58: 236-244.

Welle, B. J. H. TER \& A. M. W. Mennega (1977): On the Presence of large Styloids in the secondary Xylem of the Genus Henriettea (Melastomataceae). IAWA Bull. 1977/2: 31-35.

WISHART, E. (1969): An algorithm for hierarchical classification, Biometrics 22: 165-170.

WURDACK, J. J. (1957): Certamen Melastomataceis -IV. Brittonia 9: 101-109. 